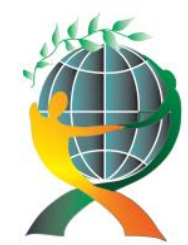

\author{
(online) $=$ ISSN $2285-3642$ \\ ISSN-L = $2285-3642$ \\ Journal of Economic Development, Environment and People \\ Volume 6, Issue 4, 2017
}

URL: http://jedep.spiruharet.ro

e-mail: office jedep@spiruharet.ro

\title{
Brain drain: Propulsive factors and consequences ${ }^{1}$
}

\author{
Dragan Ilić ${ }^{1}$, Marko Milosavljević ${ }^{2}$ \\ 1,2 Faculty of Economics and Engineering Management, Cvećarska 2, Novi Sad, 21000, Republic of Serbia \\ ${ }^{1}$ Tel: +381658539965, Fax: +381, Email: prof.dragan.ilic@gmail.com \\ ${ }^{2}$ Tel: +381631010012, Fax: +381, Email: marko.milosavljevic073@gmail.com
}

\begin{abstract}
When speaking about the total number of highly educated individuals' migration, it is easy to spot that it is rapidly increasing. The brain drain issues should be taken very seriously especially in under developed and in the developing countries, knowing that the human capital is globally mobile and that highly educated individuals can without any issues market their knowledge around the globe. Dealing with it requires a carefully tailored strategy for these countries, which are suffering from severe human capital losses on annual basis. Since the labor markets of today are highly competitive, it is necessary for these countries to secure good advancement and doing business opportunities. The purpose of this research is to provide an insight into the key propulsive factors and potential consequences caused by the brain drain. The method used in order to conduct the research was a carefully designed questionnaire taken by the date subject enrolled at the third and fourth years of state governed and privately-owned universities. This research shows that one of the key reasons for brain drain in underdeveloped and in the developing countries is shortage of further educational advancement opportunities.
\end{abstract}

Keywords: brain drain, family income, higher education, students

JEL Codes: J24 Human Capital: Skills; Occupational choice; Labor Productivity)

\section{Introduction}

TACTICS is an acronym compiled by the London School of Economics, the UCL Institute of Higher Education and Times Higher Education to describe a group of selected countries [THE, 2016].

By building a strong and high-quality education system, the economies of a country will provide further growth and development in the future [World Economic Forum, 2016]. The London School of Economics analysed nearly 15,000 universities in 78 countries and came to the conclusion that by doubling the number of higher education institutions in a particular region, GDP growth per capita is $4.7 \%$ in five years. Countries that are on the right track to achieve this are:

\footnotetext{
${ }^{1}$ The article was previous presented at International Conference on Economic Sciences and Business Administration 2017
} 


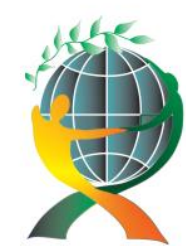

1. Thailand

2. Argentina

3. Chile

4. Turkey

5. Iran

6. Colombia

7. Serbia

Viewed from the perspective of higher education, these countries have the opportunity to take over the BRICS countries, Brazil, Russia, India, China and South Africa - the countries that traditionally dominated the production of higher education staff and the quality of the education system.

In the TACTICS countries, the GDP level is less than $\$ 15,000$ per capita, but nearly half of the young people are involved in the higher education system [THE, 2016]. Youth participation in higher education increased by $5 \%$ between 2010 and 2014; at the annual level of this country, they publish over 30,000 research papers and all have at least one university listed on THE WORLD University Rankings. This group of countries also recorded a higher Gross Tertiary enrolment ratio, i.e., the gross number of students enrolled each year by faculty from the BRICS countries.

The impact of migration of labor to the countries from which they leave, to the countries they leave, has been the subject of study for a long time. Classical literature agreed that the countries in which emigrants earn profits, while the countries from which they migrate recorded negative effects and consequences [Bhagwati and Hamada, 1974]. This phenomenon is commonly referred to as brain drain. In the framework of the studies conducted by the World Bank and the United Nations, a lot of attention was devoted to the unused potential, acquired knowledge and skills of migrants, if they cannot use the same after leaving a country. This phenomenon is called "brain waste". Recent research suggests different aspects, rather than the phenomena and consequences of leaving and unused labor and their potential after leaving. They focus on the potential benefits that a country can derive from migrants returning to the country of origin. The main benefits that are highlighted on this occasion are money remittances sent to the country of origin, as well as an experience that can potentially be used to raise the productivity of a country. This phenomenon is called brain-circulation or brain-gain.

1. Brain drain - brain drain - "For many people capital means money, shares of a particular company, bank account or real estate" [Kelo \& Wächter, 2004]. These are indeed forms of capital that generate revenue over time, but equity capital must also be added to this type of capital. Education and training are seen as key investments when it comes to the formation of human capital. Over time, they will secure the acquisition of a better job, which will result in the realization of higher income of these individuals. They are considered crucial when it comes to the impact and degree of national economies. A higher level of education of the workforce will accelerate economic prosperity. Given that the development of societies and the economies of today, on a much higher level than before, it is largely fuelled by innovations, and therefore investment in knowledge is considered more important than ever before. Since people make capital, that is, their knowledge and skills, it is lost at the moment when people emigrate. This is a loss for the country of origin and profit for the destination of these people. From a point of view of the country of origin, its earlier 


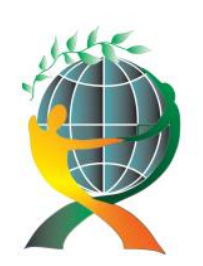

\author{
(online) $=$ ISSN $2285-3642$ \\ ISSN-L = $2285-3642$ \\ Journal of Economic Development, Environment and People \\ Volume 6, Issue 4, 2017
}

URL: http://jedep.spiruharet.ro

e-mail: office jedep@spiruharet.ro

investment in training and training will simply collapse. This loss is the highest in the case of highly qualified individuals.

2. Brain waste - Migration of highly educated people does not necessarily have to be characterized as a gain for a country destination. The case of a win is when a migrant, for example, a nuclear physicist, carries out a job in his area or in areas that match his knowledge and skills. But if he does business in the country where he went which are incompatible with his competencies such as truck drivers or waiters, this is a loss to the country of destination. In this case, the disagreement between the offered skills by the individual and those required by the labor market, experts are characterized as brain waste. Then there are double losses for both the physicist and the country he came in. The fact is that many immigrants start their professional career below their level of expertise and the former

The term "brain drain" appeared in the report of the London Royal Society in the year of 1963. in order to describe exodus of British scientists to the United States [Avveduto \& Brandi, 2004]. The term brain drain designates the international transfer of resources in the form of human capital and mainly applies to the migration of relatively highly educated individuals from developing to developed countries [Beineet al., 2008]. Human capital is an aggregate that outlines skills gained by certain individuals in terms of productive capacity [Heckman et al., 2006]. While the size of human outflow is easily and objectively measurable, it is more difficult to analyse the human capital embodied in it [Becker et al., 2004]. According to Docquier, Lohest and Marfouk (2007) the term is commonly used to describe migrations of engineers, physicians, scientists, and other very high-skilled professionals with university training. The migration pressure has increased over the last years and is expected to intensify in the coming decades given the rising gap in wages and the differing demographic futures in developed and developing countries [Docquier, 2006]. It is very important to mention that the brain drain problems have always been under the scope of controversy. Brain drain has always been a commonly accepted concern, especially for small countries where highly educated emigration rates are high. Rizvi (2005) suggest that the most of the recent discussions concerning brain drain have focused on its unfavorable economic impact on developing countries, particularly in the fields of science and technology. "When both receiving and sending economies benefit from brain drain migration, it is possible that the more advanced economy benefits more from this process and for world inequality to increase as a result" [Mountford \& Rapoport, 2007]. In a global economy which relies itself mostly upon information, rather than natural resources, it is very important for under developed and the developing countries to be able to control or at least monitor human capital outflows. Unfortunately, in most cases, due to shortage of technological solutions and the lack of financial resources they are not able to do so, although they would probably benefit the most out of it. Due to ferocious global fight for talent, it is very difficult to keep up with developed countries, which are always on the quest for "best and brightest" minds from all sorts of scientific fields.

For students who have tendencies towards migrating after they graduate, it is very important to be able to speak at least one foreign language. "English will be the language of the 'globalised' world" [Straubhaar, 2000].

The main hypothesis of the research relates itself to the relatively low total family incomes and their influence on students' decision whether to migrate, or stay in the country of origin after they graduate. When dealing with brain drain issues, like the Republic of Serbia, Hungary, Croatia have been, it is very important 


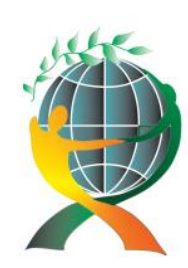

\author{
(online) $=$ ISSN $2285-3642$ \\ ISSN-L = $2285-3642$ \\ Journal of Economic Development, Environment and People \\ Volume 5, Issue 2, 2016 \\ URL: http://jedep.spiruharet.ro \\ e-mail: office jedep@spiruharet.ro
}

to identify what the key propulsive factors that indicate certain ways of demographic changes are. In spite of wide spread information on brain drain in all three countries, there is a need for precise statistical analysis in order to quantify the phenomenon and identify possible solutions to deal with it.

The importance of this paper lays in the contemporary data collected during academic year of 2017. The paper itself will try to depict current tendencies of the third and fourth year students involved in the higher education process.

\title{
2. Research methodology
}

\subsection{Submitting (Use "Header 2" style)}

The research was carried out in Novi Sad, Republic of Serbia, Budapest, Hungary and Zagreb, Croatia.

The focus group of the implemented research was constituted of the third and fourth year students. Students from 17 different university departments, who are enrolled in the fourth and third year of bachelor studies were asked to fulfil the survey while still involved in the higher education process within the Republic of Serbia, Croatia and Hungary.

They were asked various question related to the topic of brain drain. The questions were close - end and open - end depending on the required information. The survey was administered at the start of the second semester, because the total number of students is much higher on lectures. After collecting the surveys, the data collected were tabled in Windows Excel program in uniquely created table for data import, which allowed us use them later in SPSS quantitative data analysis program. Due to the importance of analysed subject, we have used multiple methodological approaches in order to complete basic methodological approaches such as objectivity and reliability.

A total of 743 questionnaires were given back, representing a $96 \%$ response rate among students in attendance at the scheduled lecture at which survey was conducted.

\section{Results}

The hypothesis refers to the correlation between the total family incomes and students' aspirations towards migration after they graduate. On the basis of the Chi-Square Test of Independence which helped us to determine whether there is a correlation between total family incomes and students aspirations toward migration, it has been concluded that there is not a significant correlation between these two variables $(\chi 2=$ $5,52 ; d f=3 ; p=0,137)$. At this point it is possible to emphasize that relatively low total family incomes are not the only propulsive factor for students to consider leaving the country of origin after they gain a certain academic title. When it comes to highly educated, able - bodied individuals it is important to mention that the overall conditions which refer to the better possibilities for self - development, better technological solutions, knowledge transfer etc. could be the additional key reasons for them to abandon the country of origin. With them leaving, countries' overall economic progress will be slowed down, since the demand for highly educated, young individuals is always high, especially in under developed and in the developing countries. It is possible to conclude that the hypothesis is proven to be correct, since the current financial state is not the only propulsive factor for student to consider moving abroad after they graduate. 


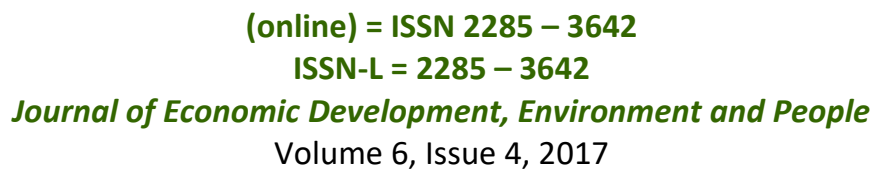

URL: http://jedep.spiruharet.ro

e-mail: office jedep@spiruharet.ro

Graphic 1. Overall grade of further self - development opportunities by the surveyed students

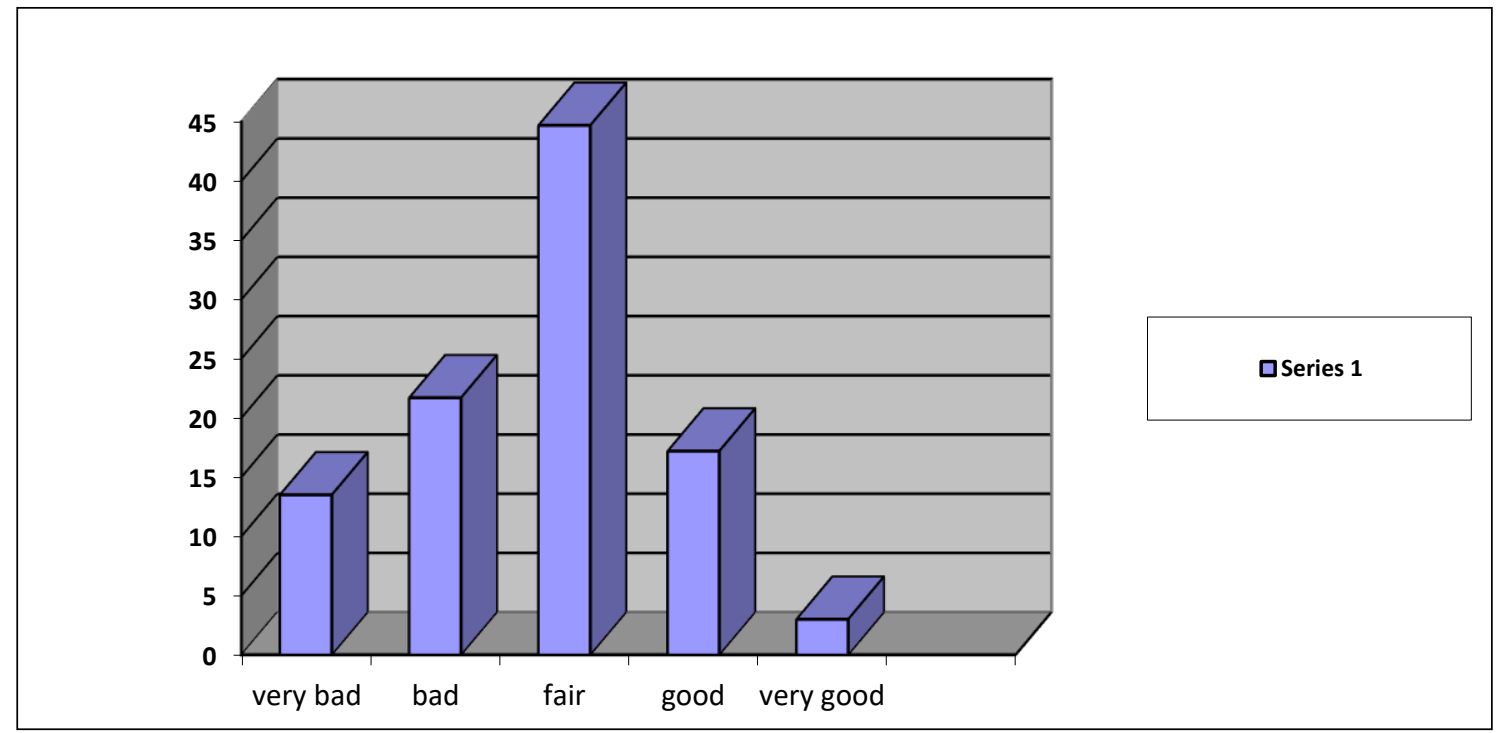

Source: Calculation made on the research basis.

The chart shown clearly depicts and contributes to proving earlier exposed facts. Due to shortage of further advancement opportunities, underdeveloped and the developing countries will suffer huge losses of human potential. 332 data subjects have graded the self - development opportunities relatively bad in comparison to these in developed countries.

Graphic 2. Better educational conditions as one of the key reasons of potential migration

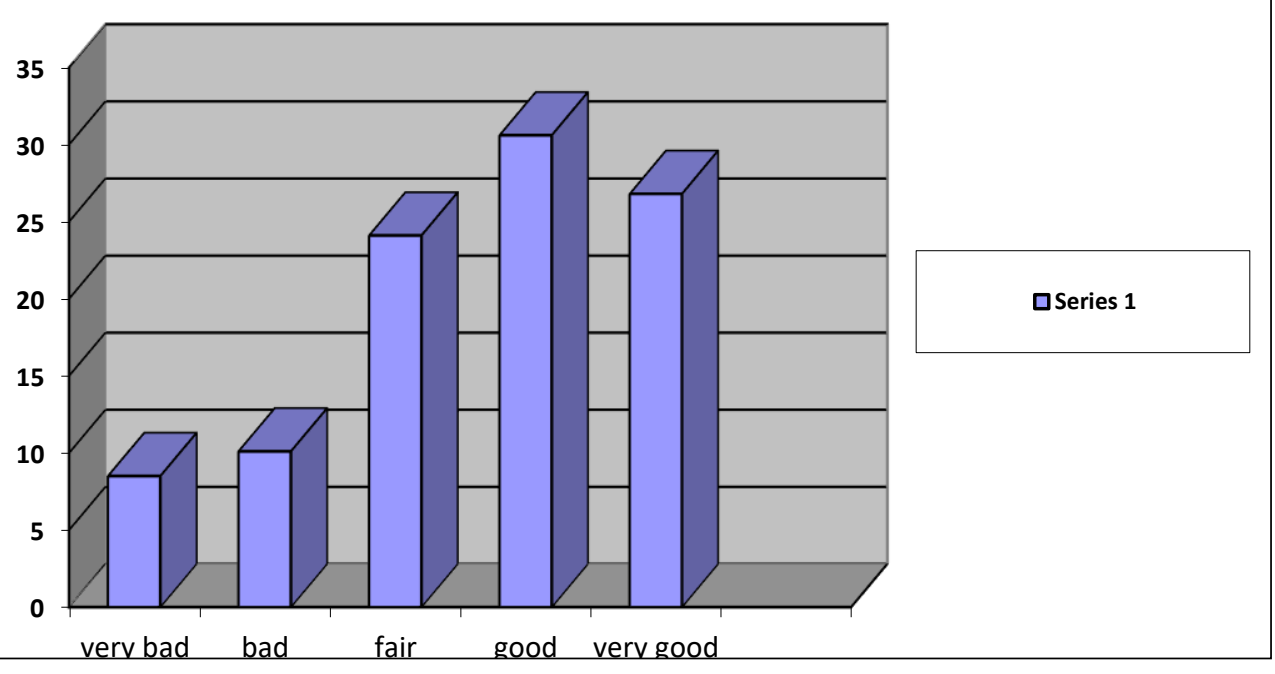

Source: Calculation made on the research basis. 


\author{
(online) $=$ ISSN $2285-3642$ \\ ISSN-L = $2285-3642$ \\ Journal of Economic Development, Environment and People \\ Volume 5, Issue 2, 2016 \\ URL: http://jedep.spiruharet.ro \\ e-mail: office jedep@spiruharet.ro
}

The graphic shown, clearly depicts that out of 743 data subjects, 426 consider better educational conditions one of the key reasons when it comes to making the decision whether to migrate or stay in the country of origin.

What also favors above showed results is the fact, that almost all of the data subject can speak at least one language, besides their mother tongue. English is the most common one as a first foreign language, which is spoken by 690 data subjects.

Graphic 3. Foreign languages

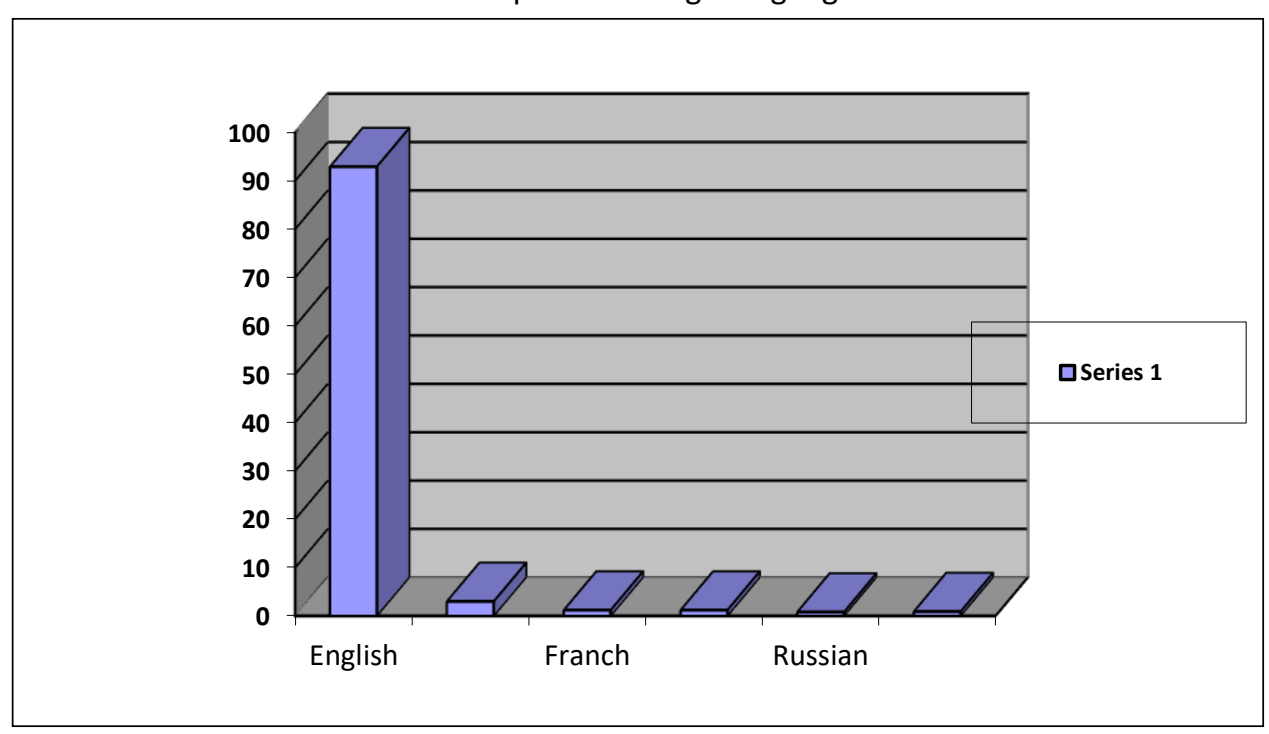

Source: Calculation made on the research basis.

What is also important to mention is the fact, that 127 data subjects, have gained internationally accepted language certificates from some of the languages.

Graphic 4. Language certificates

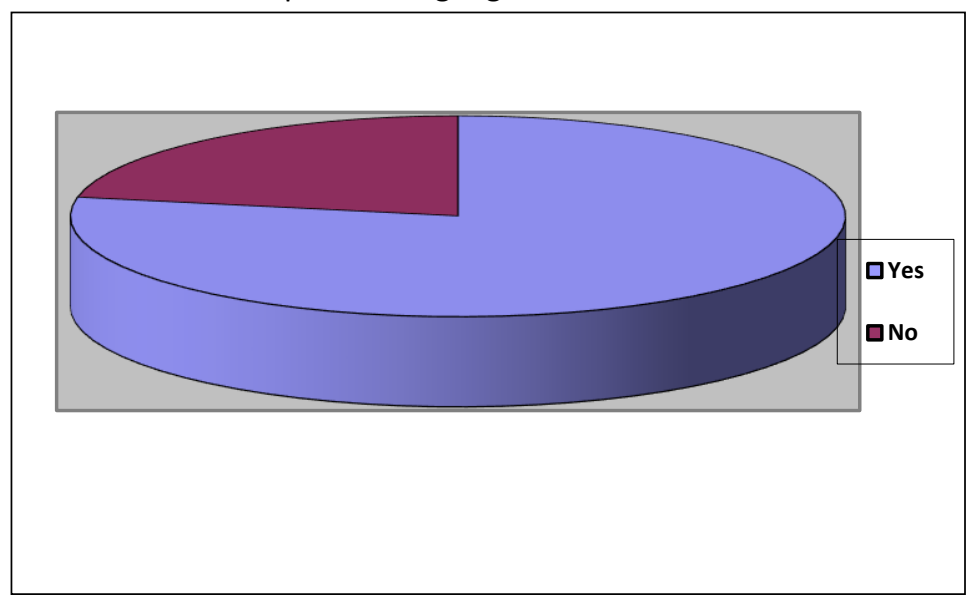

Source: Calculation made on the research basis. 


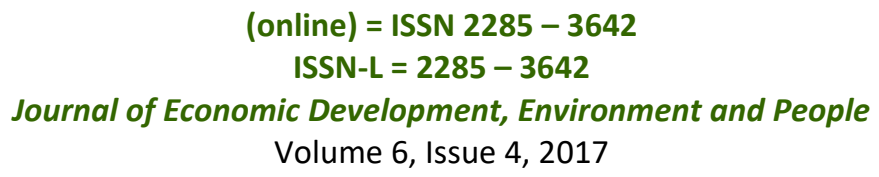

URL: http://jedep.spiruharet.ro

e-mail: office jedep@spiruharet.ro

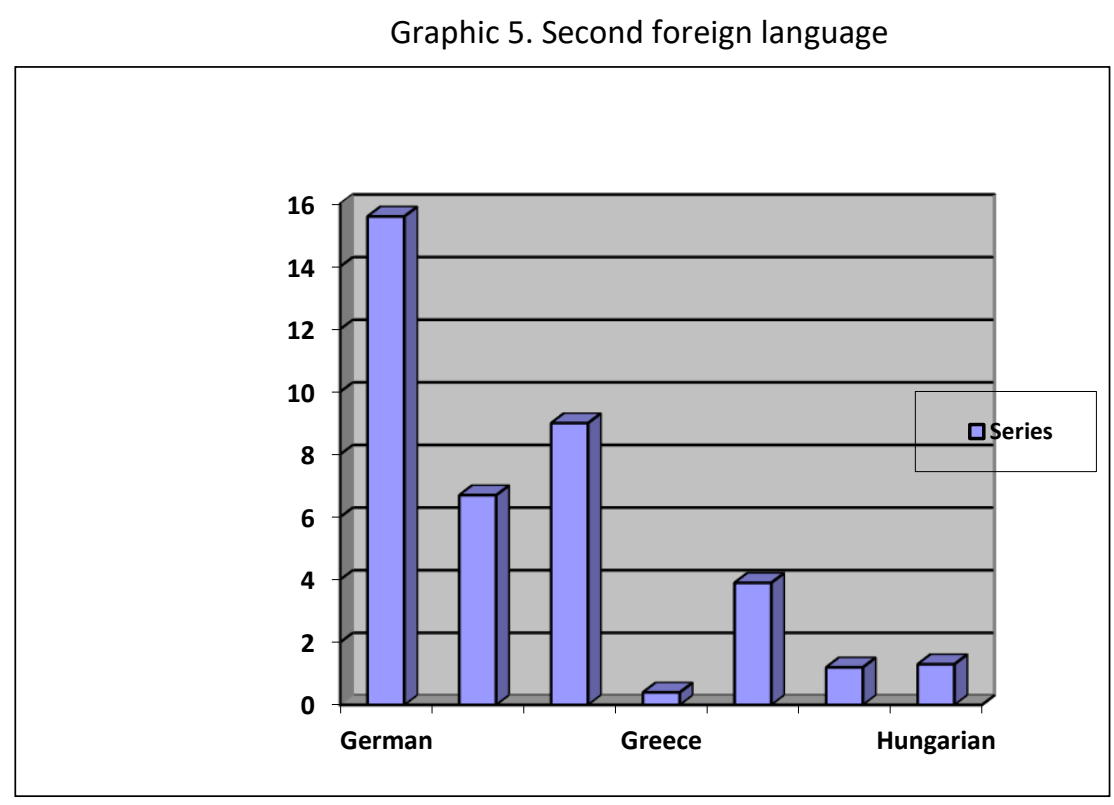

Source: Calculation made on the research basis.

From the graph shown, out of 743 respondents, 284 speak two foreign languages, of which the German language is most represented, i.e. 116 respondents speak it as a second language.

Graphic 6. Third foreign language

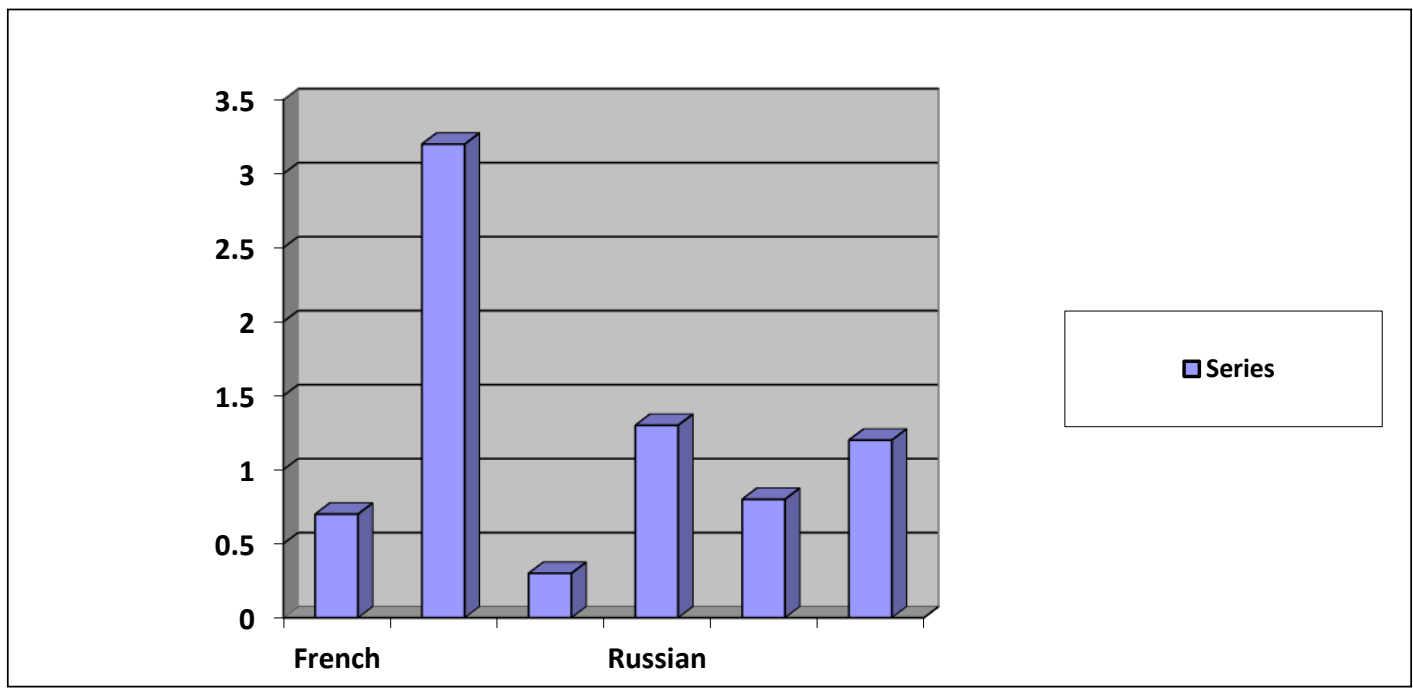

Source: Calculation made on the research basis. 


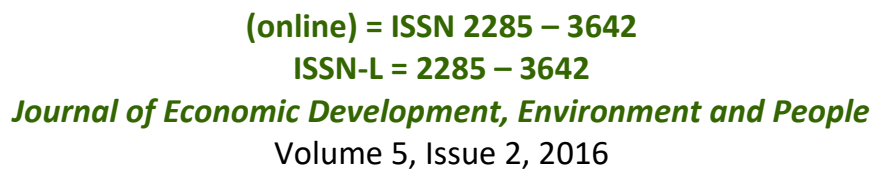

URL: http://jedep.spiruharet.ro

e-mail: office jedep@spiruharet.ro

From the graph shown, out of 743 respondents 56 of them speak three foreign languages. The Spanish language is being the most represented, i.e. 24 respondents speak it as the third language.

Graph 7. Family and friends as one of the major reasons of potential staying in home land

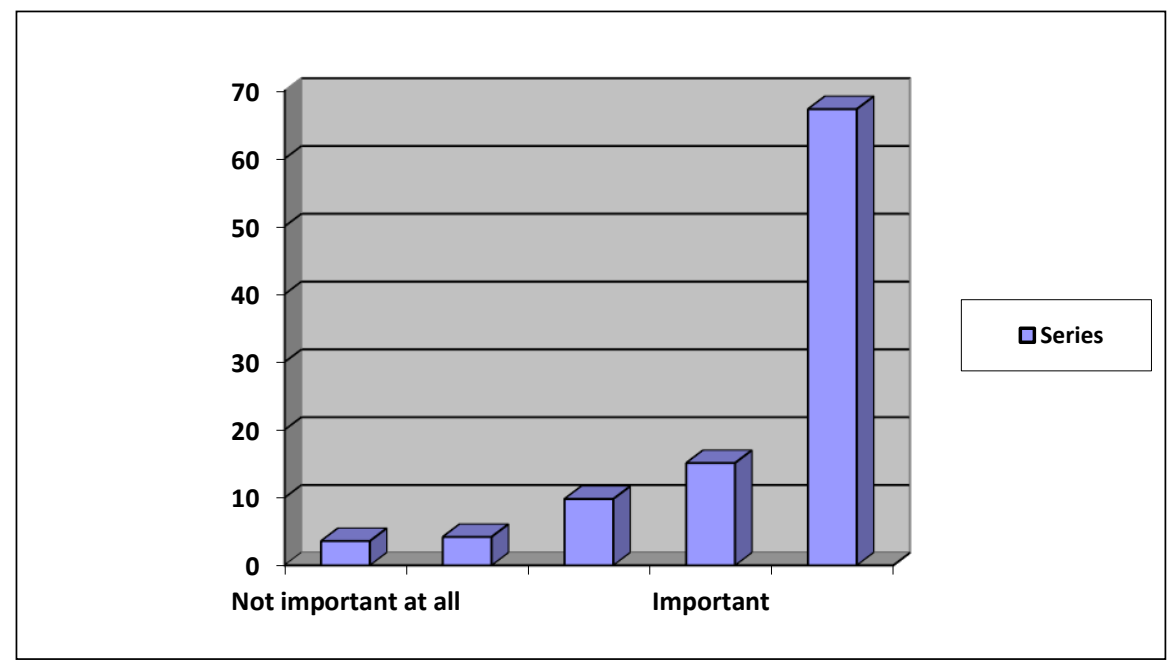

Source: Calculation made on the research basis.

Out of the total number of respondents, we note that 500 of them, "the family and friends" factor considered as a reason for a potential staying in their country a very important factor. Other reasons for the potential residency in the home country relate to the inadequate mentality of people abroad (Graph 8), patriotism (Graph 9), personal and professional achievement in the home country (Graph 10).

Graph 8. Inadequate mentality of people abroad

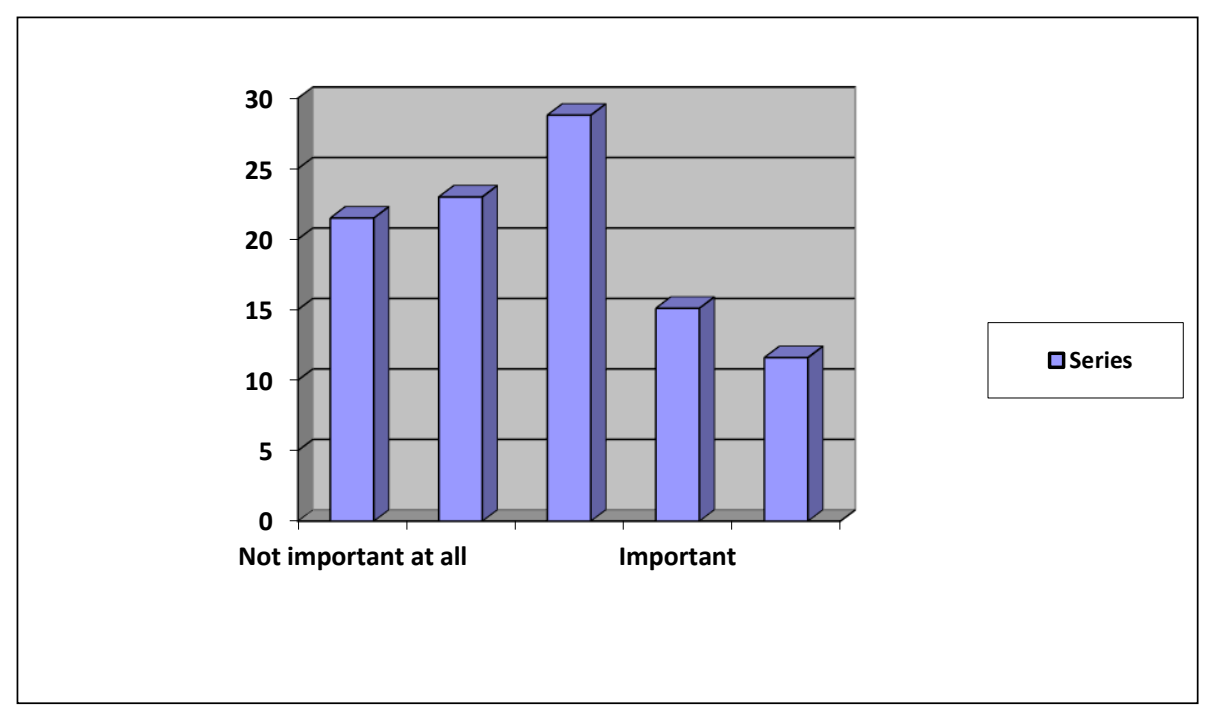

Source: Calculation made on the research basis. 


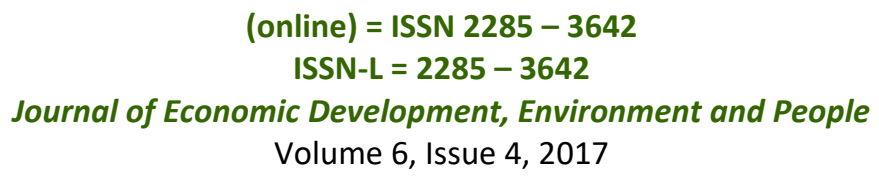

URL: http://jedep.spiruharet.ro

e-mail: office jedep@spiruharet.ro

From the graph shown can be seen that the respondents have taken a neutral attitude when it comes to the mentality of people abroad (214 of them).

Graph 9. Patriotism

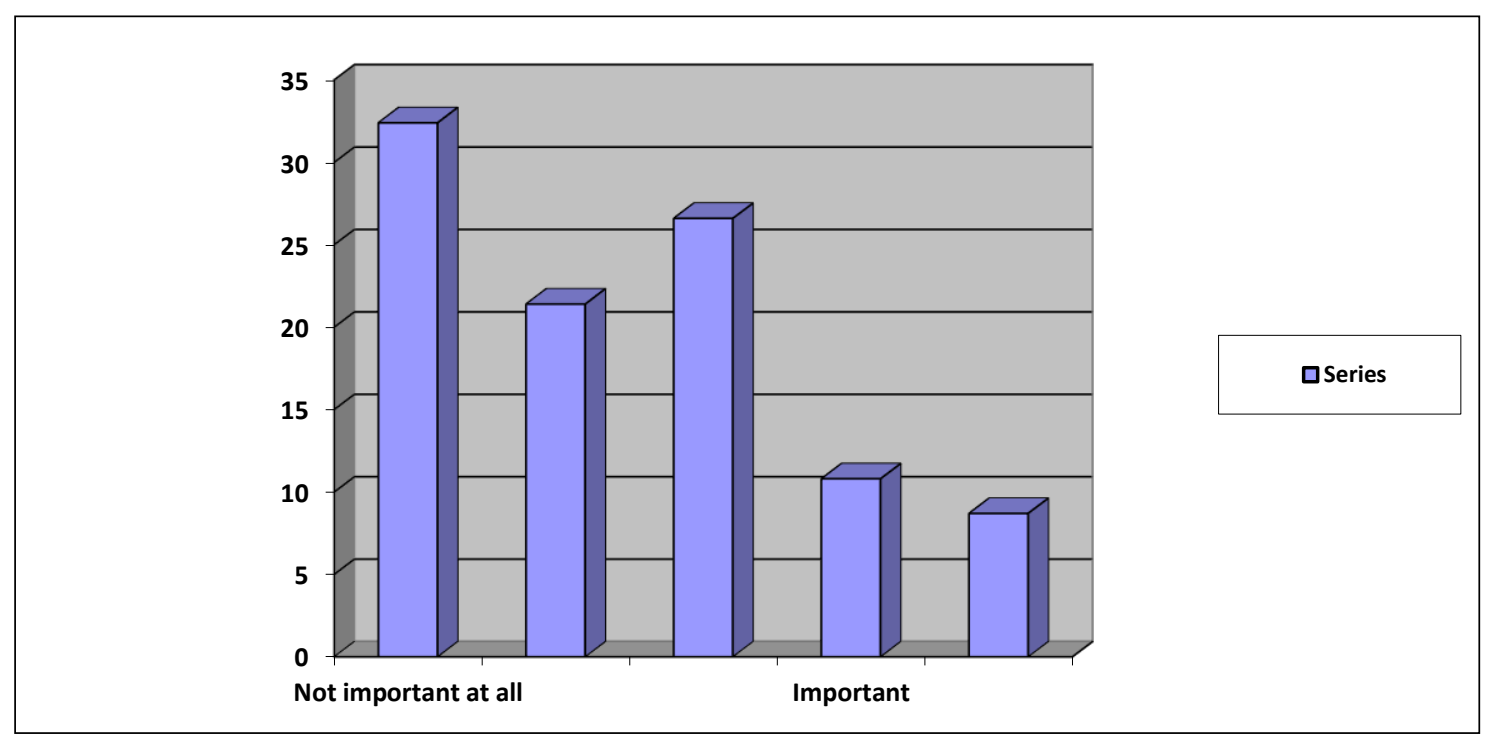

Source: Calculation made on the research basis.

From the graph shown, the majority of respondents ignored and categorized the category of patriotism as not so important. 400 respondents do not consider patriotism as a significant category when it comes to potential retention in their country.

Graph 10. Personal and professional achievement in the home country

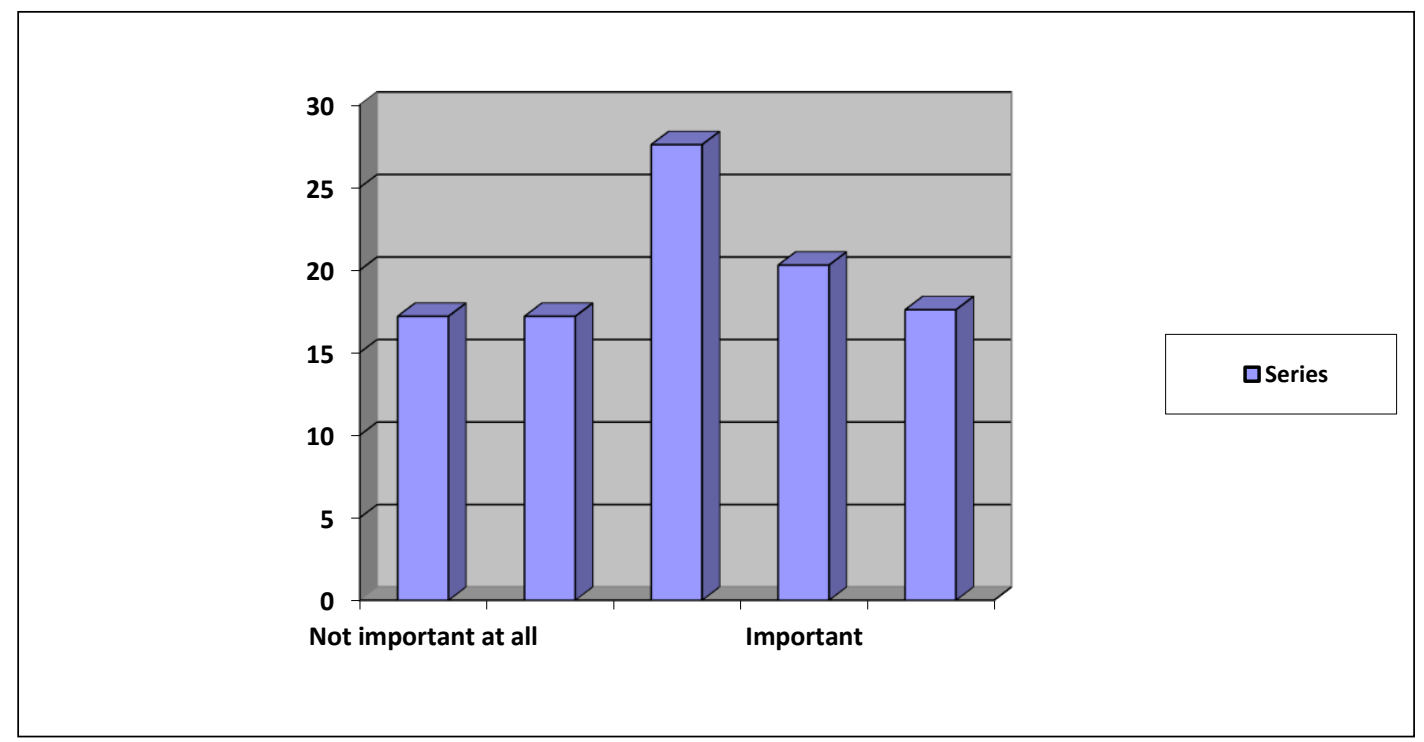

Source: Calculation made on the research basis. 


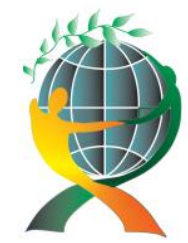

\author{
(online) $=$ ISSN $2285-3642$ \\ ISSN-L = $2285-3642$ \\ Journal of Economic Development, Environment and People \\ Volume 5, Issue 2, 2016 \\ URL: http://jedep.spiruharet.ro \\ e-mail: office jedep@spiruharet.ro
}

From the graph shown, the largest number of respondents, 205, took a neutral position when it comes to personal and professional achievement in the home land as a important factor for staying in home land.

\title{
4. Conclusion
}

Process of globalization and market liberation have greatly contributed to forming of the contemporary issues from which underdeveloped and developing countries can suffer a lot from like brain drain. By erasing boundaries for transfer of technology, knowledge, education and human capital, these countries are being greatly struck by being abandoned by highly educated individuals who will be determined to leave the country of origin if determined by better overall conditions abroad.

Dealing with brain drain issues should be taken very seriously. Clearly defined plans and strategies are required in order to identify the key reason for brain drain in time. After identifying key issues that cause it, it is necessary to find the best possible solutions and implement them rapidly in order to prevent it or at least to make human outflow process slower. By not identifying suitable solutions and without adequate suggestions, country will suffer great never retrievable losses. Without possibility to retrieve those, losses overall countries economical and societal development will be in the process of stagnation and declination. This appearance will be caused due to the shortage of highly educated individuals who could with their findings and innovations boost and develop countries' economy and society even more.

There are numerous reasons and propulsive factors which can be considered as the key ones when migrations are involved. By analysing total family incomes and students' aspirations toward migration as a result of low total family incomes, it has been shown that there is not a significant correlation between those factors. On the other hand, it has been seen that there are other propulsive factor that indicate student's aspiration toward migration and should be reconsider by the policy makers in the future. Those factors mainly relate to the better advancement and better business opportunities. By securing these, negative tendencies and aspirations towards migration, due to insufficient opportunities for further self - development, certain changes can be made on this field. Those changes would boost national economies overall progress, which can be seen through new models of knowledge based economy and will secure better future for the country itself and the people within it. If under developed and developing countries fail to address these issues in time, they will suffer major consequences in terms of further economy and society development.

\section{References}

[1] Avveduto, S., \& Brandi, M. C. (2004). Le migrazioniqualificate in Italia. StudiEmigrazione, 41(156), 797-830.

[2] Bhagwati, J., N., and K. Hamada. 1974. "The Brain Drain International Integration of Markets for Professionals and Unemployment: A Theoretical Analysis, Journal of Development Economics,1, 19-24.

[3] Borjas, G. J. (1994). Immigration and welfare, 1970-1990 (No. w4872). National Bureau of Economic Research.

[4] Docquier, Frédéric, \& AbdeslamMarfouk. "International Migration by Educational Attainment (1990-2000)-Release 1.1." database 1990 (2000): 16.

[5] Erasmus Plus. (2015). Statistics, Retrieved 15. December 2017, from http://erasmusplus.rs/mobility/statistics/

[6] Glaeser, E. L., Kallal, H. D., Scheinkman, J. A., \&Shleifer, A. (1992). Growth in cities. Journal of political economy, 100(6), 1126-1152. 


\author{
(online) = ISSN $2285-3642$ \\ ISSN-L = 2285 - 3642 \\ Journal of Economic Development, Environment and People \\ Volume 6, Issue 4, 2017 \\ URL: http://jedep.spiruharet.ro \\ e-mail: office jedep@spiruharet.ro
}

[7] Havergal, C., Opening universities linked to increased GDP, Retrieved from: https://www.timeshighereducation.com/news/opening-universities-linked-to-increased-gross-domesticproduct-gdp\#survey-answer, Accessed on December 7, 2017.

[8] Joksimović, N. Ž.,\&Benković, S. (2015). The challenges of higher education financing, Retrieved 13. December 2017, from http://www.finhed.org/media/files/Finding\%20the\%20Right\%20Path.pdf\#page=130

[9] Jöns, H. (2009). 'Brain circulation'and transnational knowledge networks: studying long-term effects of academic mobility to Germany, 1954-2000. Global Networks, 9(3), 315-338.

[10] Kapur, D., \& McHale, J. (2005). Give us your best and brightest: The global hunt for talent and its impact on the developing world. Washington, DC: Center for Global Development.

[11] Kumar, S., \&Phrommathed, P. (2005). Research methodology (pp. 43-50). Springer US.

[12] Le, T. (2008). 'Brain Drain'or 'Brain Circulation': Evidence from OECD's International Migration and R\&D Spillovers. Scottish Journal of Political Economy, 55(5), 618-636.

[13] Lingard, H. (2012). Balancing study and paid work: the experiences of construction undergraduates in an Australian university. Construction Economics and Building, 5(1), 41-47.

[14] Lucas, R., \&Lammont, N. (1998). Combining Work and Study: an empirical study of full-time students in school, college and university*. Journal of education and work, 11(1), 41-56.

[15] Mattoo, A., Neagu, I. C., \&Özden, Ç. (2008). Brain waste? Educated immigrants in the US labor market. Journal of Development Economics, 87(2), 255-269.

[16] Nakamuro, M., \& Ogawa, K. (2010). Mobility of skilled labor in transition economies: The perspectives from braindrain, brain-waist, brain circulation and brain gain. Journal of International Cooperation Studies, 18(1), 71-84.

[17] Ranjit, K. (1999). Research methodology.

[18] Schiff, M. (2005). Brain gain: claims about its size and impact on welfare and growth are greatly exaggerated.

[19] Stanković, D. (2011). Odliv mozgova kao gubitak i(li) dobitak za zemlju porekla. Godišnjak FPN, (05), 515-526.

[20] Stanojević, D., Živadinović, I., \&ČekićMarković., J. (2015). Aspirations and needs of students in Bosnia and Herzegovina, Montenegro and Serbia, Retrieved 13. December 2017, from http://www.finhed.org/media/files/Finding\%20the\%20Right\%20Path.pdf\#page=130

[21] Times Higher Education. The TACTICS countries: potential and the polity (2016). taken on 18.6.17, from https://www.timeshighereducation.com/comment/the-tactics-countries-potential-and-the-polity

[22] Tinto, V. (1987). Leaving college: Rethinking the causes and cures of student attrition. University of Chicago Press, 5801 S. Ellis Avenue, Chicago, IL 60637.

[23] United Nations (UN). (2000). Population Division. Retrieved 12. December, from http://www.un.org/en/index.html

[24] Valero, A., \& Van Reenen, J. (2016). The economic impact of universities: Evidence from across the globe (No. w22501). National Bureau of Economic Research.

[25] Vlada Republike Srbije (2011). Migracioni profil Republike Srbije za 2010. Retreived 16. December 2017, from https://serbia.iom.int/sites/default/files/publications/documents/Migracioni profil RS za 2010 godinu.pdf 


\author{
(online) = ISSN $2285-3642$ \\ ISSN-L = 2285 - 3642 \\ Journal of Economic Development, Environment and People \\ Volume 5, Issue 2, 2016 \\ URL: http://jedep.spiruharet.ro \\ e-mail: office jedep@spiruharet.ro
}

[26] World Economic Forum. (2016) These countries could be the world's new education superstars. Taken on 18.07.2017., from https://www.weforum.org/agenda/2016/12/countries-global-higher-education-superstarstactics?utm_content=buffer684d0\&utm_medium=social\&utm_source=facebook.com\&utm_campaign=buffer

[27] Ziderman, A. (2002). Alternative objectives of national student loan schemes: Implications for design, evaluation and policy. The Welsh Journal of Education, 11(1), 37-47. 